\title{
Evaluation of T Regulatory Cell Apoptosis in Children with Newly Recognized Type 1 Diabetes Mellitus
}

\author{
A. Szypowska ${ }^{1}$, A. Stelmaszczyk-Emmel ${ }^{2}$, U. Demkow ${ }^{2}$, W. Luczynski ${ }^{3}$ \\ ${ }^{1}$ Department of Pediatrics, Warsaw Medical University, Warsaw, Poland; ${ }^{2}$ Department of Laboratory Diagnostics and Clinical \\ Immunology of Developmental Age, Warsaw Medical University, Warsaw, Poland; ${ }^{3}$ Department of Pediatrics, Endocrinology, \\ Diabetology with Cardiology Division, Bialystok Medical University, Bialystok, Poland
}

\begin{abstract}
Background: Type 1 diabetes is a metabolic disease characterized by an autoimmune, T-cell dependent destruction of insulin producing pancreatic beta cells. T regulatory cells (Tregs) are critical regulators of immune tolerance.

Objective: The aim of the study was to investigate CD $4^{+}$CD $25^{\text {highFoxP3 }}$ cell apoptosis in the peripheral blood of children with newly diagnosed type 1 diabetes mellitus.

Methods: 34 children (15 girls and 19 boys) with new onset of type 1 diabetes mellitus, of the mean age 6.9 \pm 5.2 (range 0.9-17.5 yr) and 18 healthy controls (8 girls, 10 boys) of the mean age $7.3 \pm 4.6(1.9-17.5 \mathrm{yr})$ were included into the study. Flow cytometric analysis of Tregs was performed using the following markers: anti-CD4, anti-CD25 and transcription factor FoxP3. Apoptosis was measured using anti-active caspase-3 monoclonal antibody. The percentage of apoptotic cells was measured within $\mathrm{CD}^{+} \mathrm{CD} 25^{\text {high FoxP3 }}{ }^{+}$ cells.

Results and conclusion: There was no statistically significant difference in the percentage of apoptotic $\mathrm{CD} 4{ }^{+} \mathrm{CD} 25^{\text {highFox }} 3^{+}$cells between children with diabetes and healthy subjects; the median value 0 (range $0-26.8)$ vs. 0 (range $0-2.6$ ), respectively $(\mathrm{P}=0.302$ ). Further, clinical studies on a larger cohort of diabetic children are needed to evaluate $\mathrm{T}$ regulatory cell apoptosis, especially for future immune-based therapy.
\end{abstract}

Key words: children, type 1 diabetes, T regulatory cells, FoxP3, apoptosis

\section{INTRODUCTION}

Type 1 diabetes is a chronic disease characterized by an autoimmune, T-cell dependent destruction of insulin producing pancreatic $\beta$-cells and irreversible insulin deficiency. Despite modern diabetes management, many young adult diabetic patients develop diabetic complications (blindness, cardiovascular and kidney disease) $[1,2]$. Type 1 diabetes affects primarily children and is the most common endocrine and metabolic childhood disease [3]. The age at onset may be influenced by the intensity of the $\beta$-cell destruction process and it is possible that both genetic and environmental factors interfere in this process [4]. Post- mortem pathological studies of newly diagnosed patients with type 1 diabetes have shown that in children younger than 7 years the number of remaining $\beta$-cells is reduced to approximately 5\%, comparing to $20 \%$ in 17 years old adolescents [5]. The capacity of residual $\beta$-cells to secrete insulin is decreased at the time of diagnosis of type 1 diabetes, often improving in a few weeks after the initiation of exogenous insulin treatment. The absence of toxic effects of chronic hyperglycemia on $\beta$-cells can be accompanied by $\beta$-cell regeneration. This phenomenon, referred to as a remission or honeymoon period, has been defined clinically by an exogenous insulin requirement to less than 0.5 $\mathrm{U} / \mathrm{kg}$ per day [6]. Partial diabetes remission is observed mainly 7 to 10 months after its onset [7]. However, not do all subjects go through a remission phase. Preservation of beta cell function at this stage would allow beta cells regeneration and would prolong remission time [8].

Mononuclear cell infiltration into the pancreatic islets (insulitis) composed of $\mathrm{CD}^{+} \mathrm{T}, \mathrm{CD} 4^{+} \mathrm{T}$, and $\mathrm{B}$ lymphocytes and macrophages have been recognized in newly onset type 1 diabetic patients [6]. Recent advances in identification and classification of naturally occurring thymus-derived $\mathrm{T}$ regulatory cells (Tregs) highlight their crucial function in immune responses to self-tissues. Previous studies have reported that Tregs are able to suppress proliferation and cytokine production from both $\mathrm{CD}^{+}$and $\mathrm{CD} 8^{+} \mathrm{T}$-cells [10]. Abnormalities of Tregs, either in cell number or function, are associated with initiation and progression of type 1 diabetes [11]. The most common form of cell death of leukocytes is apoptosis. Central to the apoptotic process is a family of intracellular cysteine proteases with aspartate-specificity, called caspases. Almost nothing is known about the regulation of apoptosis concerning the regulatory $\mathrm{T}$ cells [12]. Deregulated apoptosis in Tregs could contribute to the pathogenesis of diabetes. Identifying mechanisms underlying the breakdown of self tolerance, leading to type 1 diabetes is of major importance especially for immune-based therapy with Tregs, combined with effective drugs to eliminate Treg-resistant effector T-cells. Such therapy could lead to the induction of long-term tolerance and preservation of $\beta$-cell mass, without the need for long-term immunosuppression [8]. 
The aim of the study was to investigate percentages of $\mathrm{CD}^{+}{ }^{+} \mathrm{CD} 25^{\text {high }} \mathrm{FoxP} 3^{+}$cell apoptosis in the peripheral blood of children with newly diagnosed type 1 diabetes in comparison with healthy controls.

\section{Material And Methods}

The study was approved by a local Ethics Committee, and informed consent was obtained from all parents and from the participants who were over 16 years old.

Thirty four children (15 girls and 19 boys) of the mean age $6.9 \pm 5.2$ years (range $0.9-17.5$ years), with newly recognized type 1 diabetes mellitus, and eighteen healthy controls ( 8 girls, 10 boys) of the mean age $7.3 \pm 4.6$ (1.9-17.5 years) were included into the study. There was no difference in age between both groups. All subjects were treated in Department of Pediatrics of the Warsaw Medical University in Warsaw, Poland. Inclusion criteria for the control group were: fasting blood glucose $<5.5 \mathrm{mmol} / \mathrm{l}$, no personal or familial history of type 1 diabetes, no signs of other autoimmune, chronic, inflammatory, and neoplasmatic disease. Type 1 diabetes mellitus was diagnosed according to ISPAD criteria [13], all patients had symptoms of hyperglycemia and a random serum glucose $>11.1$ $\mathrm{mmol} / \mathrm{l}$. Moreover, each subject with type 1 diabetes was positive of at least one $\beta$-cell autoantibodies: against glutamic acid decarboxylase (anti-GAD), anti islet cell (anti-ICA), or protein tyrosine phosphatase $\mathrm{IA}_{2}$ (anti $\mathrm{IA}_{2}$ ). All children with diabetes were treated with intensive insulin therapy; no other drugs were administered in this group. In the diabetic patients, peripheral blood samples were collected in the second week of hospitalization after obtaining metabolic compensation.

\section{FLOW CyTOMETRY}

Whole blood was collected on K-EDTA, mononuclear cells were isolated using a standard FicollHistopaque $^{\circledR} \_1077$ (Sigma Aldrich, St. Louis, MO, USA) gradient centrifugation (Sigma Diagnostic Instruction Manual). Flow cytometric analysis was performed using the following monoclonal antibodies purchased from Becton Dickinson: anti-CD4 (PE-Cy-5), antiCD25 (PE-Cy-7). Apoptosis was measured using antiactive caspase-3 monoclonal antibody (PE, Becton Dickinson). Percentage of apoptotic cells was measured within $\mathrm{CD}^{+}{ }^{+} \mathrm{CD} 25^{\text {high FoxP }} 3^{+}$cells. Intracellular staining for the assessment of FoxP3 (Alexa Fluor 488 ) and active caspase- 3 (PE) was performed according to the manufacturer's instructions (Human FoxP3 Buffer Set from Beckton Dickinson). Appropriate isotype control antibodies were used. Samples were evaluated on Cytomics FC500 flow cytometer (Beckmann Coulter).

Percentages of positive cells were calculated. To determine absolute cell counts, a small volume of blood was analyzed for complete blood count. Absolute counts were determined by multiplying the frequency of positive cells determined in a cytometric analysis by the number of lymphocytes $\mathrm{x} 10^{3} / \mu \mathrm{l}$ as determined by complete blood count.

\section{STATISTICAL ANALYSIS}

Results are presented as means $\pm \mathrm{SD}$ and for non-parametric data as medians. The age comparison between groups was made using an unpaired $t$-test. Due to asymmetric data distribution (Kolmogorov-Smirnov and Shapiro-Wilk tests) non-parametric tests were used to analyze the results from flow cytometry. The results in the examined and control group were compared using the Mann-Whitney U test. The analysis was performed using GraphPad Prism 5.0 (GraphPad Software, USA). The graph was prepared in GraphPad Prism 5.0. $\mathrm{P}<0.05$ was considered as significant.

\section{RESULTS}

The mean value of glycated hemoglobin $\mathrm{HbA}_{1 \mathrm{c}}$ in the diabetic children was $11.9 \%$ (range $7.9-17.0 \%$ ). The absolute count of white blood cells, number, and percentage of lymphocytes and $\mathrm{CD}^{+}$in the peripheral blood were similar in both diabetic and control groups (data not shown).

There was no statistical difference in the percentage of apoptotic $\mathrm{CD} 4{ }^{+} \mathrm{CD} 25^{\text {high }} \mathrm{FoxP} 3{ }^{+}$cells between the diabetic and healthy children; the median value 0 (range 0-26.8) vs. 0 (range 0-2.6), respectively; $\mathrm{P}=$ 0.302 (Fig. 1).

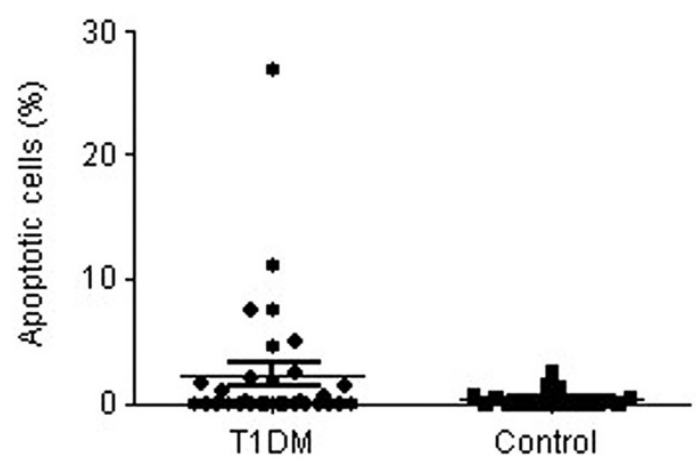

Fig. 1. Comparison of percentages of apoptotic $\mathrm{CD} 4^{+}$ $\mathrm{CD}^{2} 5^{\text {high }} \mathrm{FoxP}^{+}$cells between children with diabetes and healthy subjects.

\section{Discussion}

In the present study, there was no statistical difference between the percentages of apoptotic $\mathrm{CD} 4{ }^{+} \mathrm{CD} 25^{\text {high- }}$ $\mathrm{FoxP}^{+} \mathrm{T}$ regulatory cells in children with type 1 diabetes compared with healthy controls. There are only a few studies evaluating $T$ regulatory cell apoptosis in diabetic patients. Difference in the criteria used to define the cell population may partly explain the discordance between those studies and our present results. Treg cells represent $\mathrm{CD} 4{ }^{+} \mathrm{T}$-cell population expressing CD25 ( $\alpha$-chain of interleukin 2$)$. In peripheral blood about $10 \%$ of $\mathrm{CD}^{+}$cells express CD25 receptor, but only $2-4 \%$ of total CD4 $\mathrm{T}$ cells in peripheral blood, with high expression of CD25, have the regulatory properties [14]. The naturally occurring Tregs, except for high CD25 expression, are characterized by transcription factor FoxP3 ${ }^{+}$presence. FoxP3 ${ }^{+}$has been 
proposed as the master regulator of Treg cells that controls the expression of multiple genes that mediate their regulatory activity [15]. In human, disruption of Foxp $^{+}$function leads to an immune dysfunction, polyendocrinopathy, enteropathy, and X-linked (IPEX) syndrome characterized by autoimmune disease, allergy, and inflammatory bowel disease. In mice, deletion of $\mathrm{FoxP}^{+}$cells leads to multi-organ autoimmune disease, highlighting the key role of $\mathrm{FoxP}^{+}$in the function of Tregs [16].

Divergent results have been obtained by GlisicMilosavljevic et al $[17,18]$ concerning the percentage of $\mathrm{CD}^{+}{ }^{+} \mathrm{CD} 25^{\text {high }} \mathrm{T}$ regulatory cell apoptosis in recent-onset type 1 diabetic patients. In one study, they have observed higher levels of $\mathrm{CD} 4{ }^{+} \mathrm{CD} 25^{\text {high }} \mathrm{T}$ cell apoptosis in the patients and in their unaffected relatives, who were positive for multiple antibodies compared with healthy controls [17]. However, in another study $\mathrm{CD}^{+} \mathrm{CD} 25^{\text {high }}$ Treg cell apoptosis in diabetic children did not differed from that in healthy subjects [18]. The findings of our present study are in line with the latter. The lack of a difference in apoptotic $\mathrm{CD} 4{ }^{+} \mathrm{CD} 25^{\text {highFoxP3}}{ }^{+} \mathrm{T}$ regulatory cells in recent-onset diabetic children may indicate that the immune process varies between children and adults with type 1 diabetes. It is possible that the dynamics of $\beta$-cell destruction are different in both groups, being more intense in affected children.

It is also probable that the dynamics of programmed death of Tregs have an influence on the function of remaining beta cells, clinically expressed as a partial diabetes remission. Glisic-Milosavljevic et al [18] have shown increased levels of $\mathrm{CD} 4^{+} \mathrm{CD} 25^{\text {high }} \mathrm{T}$ cell apoptosis detected in the period of metabolic stabilization in most patients with type 1 diabetes within 6 months after recognition. In that study, apoptosis of CD $4^{+} \mathrm{CD} 25^{\text {high }} \mathrm{T}$ cells has been decreasing with the time of partial remission. The end of remission was determined by both decreased apoptosis and increased total insulin dose. Low Tregs apoptosis has been observed in pediatric patients in the post-remission period (more than 6 months from the diagnosis) and in patients with long-standing type 1 diabetes.

Yan et al [19] have examined the hypothesis that the progression of diabetes is partially due to the weakened survival of CD25high $\mathrm{T}$ cells. They have observed that prolonging survival of CD25high $\mathrm{T}$ cells inhibits the development of autoimmune diabetes due to survival of suppressive Tregs and decreased expression of pancreatic TNF- $\alpha$. These authors suggest that modulation of Tregs survival can become a new therapy for autoimmune diseases.

It can be speculated that differences in the percentage of $\mathrm{CD}^{+}{ }^{+} \mathrm{CD} 25^{\text {high }} \mathrm{FoxP}^{+} \mathrm{T}$ regulatory cell apoptosis among our patients with type 1 diabetes might be caused by different severity of autoimmune process at diabetes onset. Higher percentages of Tregs apoptosis in some children may be due to increased residual beta cell function and an earlier beginning of a partial remission.

The Tregs apoptosis may be influenced not only by the severity of autoimmune processes, but also by genetic predispositions. The alleles at the HLA-DRB1 and DQB1 loci are major genetic determinants of type
1 diabetes [20]. Glisic et al [21] have found an association of the HLA DQB1 genotype with the $\mathrm{CD} 4^{+} \mathrm{CD} 25^{\text {thigh }}$ T-cell apoptosis. Unaffected, autoantibody-negative high risk HLA DQB1 control subjects show increased $\mathrm{CD} 4^{+} \mathrm{CD} 25^{\text {thigh }}$ apoptosis compared with low risk HLA DQB1 control subjects, confirming that the association precedes the disease.

In summary, we have determined that the percentage of $\mathrm{CD}^{+}{ }^{+} \mathrm{CD} 25^{\text {highFoxP }} 3^{+} \mathrm{T}$ regulatory cell apoptosis in children with newly recognized type 1 diabetes remains similar to that in healthy controls. Age-dependent clinical studies on larger cohorts of diabetic children are needed to evaluate $\mathrm{T}$ regulatory cell apoptosis, especially for future immune-based therapy.

Conflicts of interest: The authors declare no conflict of interest in relation to this article.

\section{REFERENCES}

1. Schiel R, Franke S, Appel T, Voigt U, Ross IS, KientschEngel R, Müller UA, Stein G. Improvement of the quality of diabetes control and decrease in the concentrations of AGE-products in patients with type 1 and insulin-treated type 2 diabetes mellitus: results from a 10 year-prospective, population-based survey on the quality of diabetes care in Germany (JEVIN). Eur J Med Res 2004; 9: 391-9.

2. Schiemann U, Ferhat A, Götzberger M, Kaiser C, Stief J, Landgraf R, Dieterle C. Prevalence of cholecystolithiasis and its management among kidney/pancreas-transplanted type 1 (insulin-dependent) diabetic patients. Eur J Med Res 2008; 31: 127-30.

3. Zipris D. Epidemiology of type 1 diabetes and what animal models teach us about the role of viruses in disease mechanisms. Clin Immunol 2009; 131: 11-23.

4. Pirot P, Cardozo AK, Eizirik DL. Mediators and mechanisms of pancreatic $\beta$-cell death in type 1 diabetes. Arq Bras Endocrinol Metabol 2008; 52: 156-65.

5. Gepts W. Pathologic anatomy of the pancreas in juvenile diabetes mellitus. Diabetes 1965; 14: 619-33.

6. Abdul-Rasoul M, Habib H, Al-Khouly M. 'The honeymoon phase' in children with type 1 diabetes mellitus: frequency, duration, and influential factors. Pediatr Diabetes 2006; 7: 101-7.

7. Chase HP, MacKenzie TA, Burdick J, Fiallo-Scharer R, Walravens P, Klingensmith G, Rewers M. Redefining the clinical remission period in children with type 1 diabetes. Pediatr Diabetes 2004; 5: 16-9.

8. Brusko T, Bluestone J. Clinical application of regulatory $T$ cells for treatment of type 1 diabetes and transplantation. Eur J Immunol 2008; 38: 931-4.

9. Moriwaki M, Itoh N, Miyagawa J, Yamamoto K, Imagawa A, Yamagata K, Iwahashi H, Nakajima H, Namba M, Nagata S, Hanafusa T, Matsuzawa Y. Fas and Fas ligand expression in inflamed islets in pancreas sections of patients with recent onset type I diabetes mellitus. Diabetologia 1999; 42: 1332-40.

10. Piccirillo CA, Shevach EM. Cutting edge: control of $\mathrm{CD} 8{ }^{+} \mathrm{T}$-cell activation by $\mathrm{CD} 4{ }^{+} \mathrm{CD} 25^{+}$immunoregulatory cells. J Immunol 2001; 167: 1137-40.

11. Pop SM, Wong CP, Culton DA, Clarke SH, Tisch R. Single cell analysis shows decreasing FoxP3 and TGF- $\beta_{1}$ coexpressing $\mathrm{CD} 4{ }^{+} \mathrm{CD} 25^{+}$regulatory $\mathrm{T}$ cells during autoimmune diabetes. J Exp Med 2005; 201: 1333-46.

12. Simon HU. Cell death in allergic diseases. Apoptosis 2009; 14: 439-46.

13. Craig M, Hattersley A, Donaghue K. Definition, epidemiology, diagnosis and classification of diabetes in children and adolescents. Pediatr Diabetes 2009; 10: 3-12. 
14. Vrabelova Z, Hrotekova Z, Hladikova Z, Bohmova K, Stechova K, Michalek J. CD127- and FoxP3 ${ }^{+}$expression on $\mathrm{CD} 25^{+} \mathrm{CD} 4{ }^{+} \mathrm{T}$ regulatory cells upon specific diabetogeneic stimulation in high-risk relatives of type 1 diabetes mellitus patients. Scand J Immunol 2008; 67: 404-10.

15. Vignali DA, Collison LW, Workman CJ. How regulatory T cells work. Nat Rev Immunol 2008; 8: 523-32.

16. Sojka DK, Huang YH, Fowell DJ. Mechanisms of regulatory T-cell suppression - a diverse arsenal for a moving target. Immunology 2008; 124: 13-22.

17. Glisic-Milosavljevic S, Waukau J, Jailwala P, Jana S, Khoo HJ, Albertz H, Woodliff J, Koppen M, Alemzadeh R, Hagopian W, Ghosh S. At risk and recent-onset type 1 diabetic subjects have increased apoptosis in the CD $4^{+}$CD $25^{\text {thigh }}$ T cell fraction. Plos ONE 2007; 2: 1-7.

18. Glisic-Milosavljevic S, Wang T, Koppen M, Kramer J, Ehlenbach S, Waukau J, Jailwala P, Jana S, Alemzadeh R, Ghosh S. Dynamic changes in $\mathrm{CD} 4^{+} \mathrm{CD} 25^{\text {thigh }} \mathrm{T}$-cell apoptosis after the diagnosis of type 1 diabetes. Clin Exp Immunol 2007; 150: 75-82.

19. Yan Y, Xiong Z, Zhang S, Song J, Huang Y, Thornton AM, Wang H, Yang XF. CD25high $T$ cells with a prolonged survival inhibit development of diabetes. Int J Immunopathol Pharmacol 2008; 21: 767-80.
20. Erlich H, Valdes AM, Noble J, Carlson JA, Varney M, Concannon P, Mychaleckyj JC, Todd JA, Bonella P, Fear AL, Lavant E, Louey A, Moonsamy P. Type 1 Diabetes Genetics Consortium. HLA DR-DQ haplotypes and genotypes and type 1 diabetes risk: analysis of the type 1 diabetes genetics consortium families. Diabetes 2008; 57 : 1084-92.

21. Glisic S, Klinker M, Waukau J, Jailwala P, Jana S, Basken J, Wang T, Alemzadeh R, Hagopian W, Ghosh S. Genetic association of HLA DQB1 with $\mathrm{CD} 4{ }^{+} \mathrm{CD} 25^{+}$T-cell apoptosis in type 1 diabetes. Genes Immun 2009; 10: 3440.

Address for correspondence:

Agnieszka Szypowska

1, Dzialdowska St.

01-184 Warsaw

Poland

Phone/fax: +48 224523309

E-mail: agnieszka.szypowska@gmail.com 